\title{
Serum tryptase, mast cells positive to tryptase and microvascular density evaluation in early breast cancer patients: possible translational significance
}

\author{
Ilaria Marech', Michele Ammendola², Rosario Sacco², Gennaro Stefano Capriuolo ${ }^{3}$, Rosa Patruno ${ }^{3}$, \\ Rosangela Rubini ${ }^{3}$, Maria Luposella ${ }^{4}$, Valeria Zuccalà ${ }^{5}$, Eufemia Savino ${ }^{6}$, Cosmo Damiano Gadaleta', \\ Domenico Ribatti ${ }^{7,8^{*}}$ and Girolamo Ranieri ${ }^{1}$
}

\begin{abstract}
Background: Tryptase is a serine protease released from mast cells that plays a role in tumor angiogenesis. In this study we aimed to evaluate serum tryptase levels in 105 female early breast cancer patients before (STLBS) and after (STLAS) radical surgical resection, mast cell density positive to tryptase (MCDPT) and microvascular density (MVD).

Methods: STLBS and STLAS were assessed using the UniCAP Tryptase Fluoroenzyme immunoassay. Tumor sections were immunostained with a primary anti-tryptase antibody and an anti-CD-34 antibody by means of immunohistochemistry.

Results: The mean \pm 1 standard deviation STLBS and STLAS was $7.18 \pm 2.63 \mu \mathrm{g} / \mathrm{L}$, and $5.13 \pm 2.21$ respectively and a significant difference between mean levels was found $(p=0.0001)$ by student t-test. A strong correlation between STLBS and MVD ( $r=0.81, p=0.0001)$; STLBS and MCDPT ( $r=0.69, p=0.003)$; and MCDPT and MVD $(r=0.77 ; p=0.0001)$ was found.

Conclusions: Results demonstrated higher STLBS in breast cancer patients, indicating an involvement of MC tryptase in breast cancer angiogenesis. Therefore, serum tryptase levels may play a role as a novel surrogate angiogenic marker predictive of response to radical surgery in breast cancer patients. In this patients setting, it's intriguing to hypothesize that tryptase inhibitors might be evaluated in clinical trials.
\end{abstract}

Keywords: Angiogenesis, Breast cancer, Surrogate marker, Mast cells, Serum tryptase, Tissue tryptase

\section{Background}

Published data suggest that mast cells (MCs) have a dual role in the regulatory function between inflammatory and tumor cells. Interestingly, MCs induce tumor development and progression angiogenesis-mediated by means of the release of various angiogenic molecules such as Vascular Endothelial Growth Factor (VEGF), Fibroblast Growth Factor-2 (FGF-2), tryptase, chymase. On the other

\footnotetext{
* Correspondence: domenico.ribatti@uniba.it

${ }^{7}$ Department of Basic Medical Sciences, Neurosciences and Sensory Organs, University of Bari Medical School, Bari, Italy

${ }^{8}$ National Cancer Institute "Giovanni Paolo II", Bari, Italy

Full list of author information is available at the end of the article
}

hand, MCs may induce apoptosis of malignant cells by means of the release of several cytokines such as interleukin-4 and Tumour Necrosis Factor [1-5].

Several experimental studies have already demonstrated that MCs are involved in tumor macroscopic expansion and development [6-9]. Interestingly, it has been also shown that MCs density (MCD) is strongly related to angiogenesis in animal and human malignancies [3,9-22]. Among pro-angiogenic factors released from MCs tryptase is one of the most powerful. It has been demonstrated that tryptase induces in vitro microvascular endothelial cells proliferation in the matrigel 
assay and displayed in vivo the capillary growth in the chick embryo chorioallantoic membrane [23-25].

Tryptase is an agonist of the proteinase-activated receptor-2 (PAR-2) in vascular endothelial cells and breast cancer cells that in turn stimulates their proliferation [24]. Tryptase also induces angiogenesis by release of stored angiogenic factors bound to the extracellular matrix [26-29]. Very little data have been published regarding the role of tissue $\mathrm{MCs}$ density positive to tryptase (MCDPT) in breast cancer (BC) angiogenesis and development $[7,8,30]$. Moreover, no reports are available about the role of serum tryptase in $\mathrm{BC}$ angiogenesis and as a circulating predictive surrogate marker.

Therefore, in the present study we aimed to evaluate serum tryptase levels in BC patients before (STLBS) and after (STLAS) radical surgical resection and MCDPT and microvascular density (MVD) in a series of tumor tissue from early $\mathrm{BC}$ patients to correlate each to other.

Table 1 MCDPT and MVD expression, STLBS and STLAS levels as a function of clinicopathological characteristics in a series of 105 breast cancer patients

\begin{tabular}{|c|c|c|c|c|c|}
\hline Variable & $\begin{array}{c}\text { No. of } \\
\text { patients }\end{array}$ & $\begin{array}{l}\text { No. of tumours with high } \\
M C D P T^{*}(\%)\end{array}$ & $\begin{array}{l}\text { No. of tumours with } \\
\text { high } M V D^{* *}(\%)\end{array}$ & $\begin{array}{l}\text { No. of tumours with high } \\
\text { STLBS*** (\%) }\end{array}$ & $\begin{array}{l}\text { No. of tumours with high } \\
\left.\text { STLAS**** }^{*} \%\right)\end{array}$ \\
\hline \multicolumn{6}{|l|}{ Age, years } \\
\hline Range 26-86 & 105 & & & & \\
\hline Median 58 & 105 & & & & \\
\hline$<58$ years & 48 & $25(53)$ & $29(58)$ & $26(55)$ & $27(56)$ \\
\hline$\geq 58$ years & 57 & $33(58)$ & $29(51)$ & $31(54)$ & $27(48)$ \\
\hline \multicolumn{6}{|l|}{ Menopausal status } \\
\hline Premenopausal & 43 & $24(55)$ & $21(49)$ & $23(53)$ & $25(59)$ \\
\hline Postmenopausal & 62 & $36(58)$ & $31(50)$ & $32(52)$ & $34(55)$ \\
\hline \multicolumn{6}{|l|}{ Hystological type } \\
\hline Ductal & 78 & $41(52)$ & $37(47)$ & $38(49)$ & $40(51)$ \\
\hline Lobular & 27 & $14(51)$ & $16(58)$ & $13(48)$ & $15(55)$ \\
\hline \multicolumn{6}{|l|}{ Tumour size } \\
\hline $\mathrm{pT}_{1}$ & 49 & $26(54)$ & $25(55)$ & $27(55)$ & $24(49)$ \\
\hline $\mathrm{pT}_{2}$ & 36 & $16(44)$ & $19(52)$ & $18(51)$ & $17(47)$ \\
\hline $\mathrm{pT}_{3}$ & 20 & $12(59)$ & $11(54)$ & $10(50)$ & $9(47)$ \\
\hline \multicolumn{6}{|l|}{ Nodal status } \\
\hline $\mathrm{pN}_{0}$ & 44 & $19(43)$ & $21(48)$ & $20(46)$ & $23(52)$ \\
\hline $\mathrm{pN}_{1-2}$ & 61 & $29(48)$ & $32(53)$ & $33(54)$ & $35(58)$ \\
\hline \multicolumn{6}{|c|}{ Cytohistological grade } \\
\hline $\mathrm{G}_{1}$ & 37 & $19(52)$ & $22(60)$ & $21(58)$ & $18(48)$ \\
\hline $\mathrm{G}_{2}$ & 45 & $20(44)$ & $23(51)$ & $21(47)$ & $22(49)$ \\
\hline $\mathrm{G}_{3}$ & 23 & $12(54)$ & $10(45)$ & $11(50)$ & $13(56)$ \\
\hline \multicolumn{6}{|c|}{ Estrogen receptor status } \\
\hline Negative & 29 & $16(55)$ & $17(58)$ & $13(46)$ & $14(55)$ \\
\hline Positive & 76 & $37(49)$ & $42(55)$ & $36(48)$ & $41(54)$ \\
\hline \multicolumn{6}{|c|}{ Progesteron receptor status } \\
\hline Negative & 34 & $19(55)$ & $16(47)$ & $18(53)$ & $17(50)$ \\
\hline Positive & 71 & $36(51)$ & $35(49)$ & $39(55)$ & $37(52)$ \\
\hline \multicolumn{6}{|l|}{ c-erbB-2 status } \\
\hline Negative & 69 & $37(54)$ & $33(48)$ & $35(51)$ & $37(53)$ \\
\hline Positive & 36 & $22(61)$ & $20(55)$ & $19(52)$ & $17(48)$ \\
\hline
\end{tabular}

*Median cut-off value: 8 cells per 400 field.

**Median cut-off value: 23 microvessels per 400 field.

***Median cut-off value: 6.4 .

****Median cut-off value: 4.8 . 
The possible role of serum tryptase as predictive surrogate marker of radical surgery has been also evaluated. In this context tryptase inhibitors (gabexate and nafamostat mesylate) might be evaluated in adjuvant clinical trials as a new anti-angiogenic strategy.

\section{Methods}

\section{Study populations}

The clinicopathological features of the patients are summarized in the Table 1. A series of $105 \mathrm{BC}$ patients observed at the Clinical Surgery Unit of the "Magna Graecia" University of Catanzaro were selected. Biopsy specimens were collected from 105 female BC patients who had undergone $\mathrm{BC}$ surgery. Patients were selected accordingly the presence of a primary, invasive breast tumor (stage T1-T3), the presence or not of metastases in axillary lymph nodes (stage N0-N2), the absence of distant metastases (M0), the presence of unilateral breast cancer and the absence of previous or concomitant primary cancer. Patients were staged according to the International Union Against Cancer Tumor Node Metastasis (UICC-TNM) classification [31]. They not received neo-adjuvant therapies nor other medications that could interfere with serum tryptase levels. Surgical treatment performed was either a modified radical mastectomy (39 patients in which the tumor had a diameter $>3 \mathrm{~cm}$ ) or a quadrantectomy with axillary lymphadenectomy. No patient was subjected to the investigation of sentinel lymph node. Following surgery, a course of 5-6 weeks of radiation therapy (66 patients) was performed. On the basis of clinicopathological features patients were evaluated to receive adjuvant hormonal therapy or chemotherapy or both. Full ethical approval and signed consent from individual patients were obtained to conduct the study. The full name of ethics institutional committee review board that approved our study is: University Hospital Ethics Committee "Mater Domini", Germaneto, Catanzaro, Italy.

\section{Sample preparation}

Blood samples were collected one day before and one day after surgery. Than samples were dispensed into test tubes with serum separator tubes (Becton Dickinson Vacutainer Systems Hemogard, Plymouth, UK) and left for at least $30 \mathrm{~min}$ at room temperature. The samples were subsequently centrifuged at $1,500 \times \mathrm{g}$ for $15 \mathrm{~min}$ at room temperature and the supernatant was recovered. Patient sera were frozen at $-80^{\circ} \mathrm{C}$. Starting the analytical phase, sera were thawed to room temperature and mixed thoroughly by vortexing at low speed in order to eliminate any particulate matter affecting reproducible results. Serum tryptase levels were measured by fluoro-enzymeimmunoassay (FEIA) using Uni-CAP100 (Pharmacia Diagnostics AB, Uppsala, Sweden).

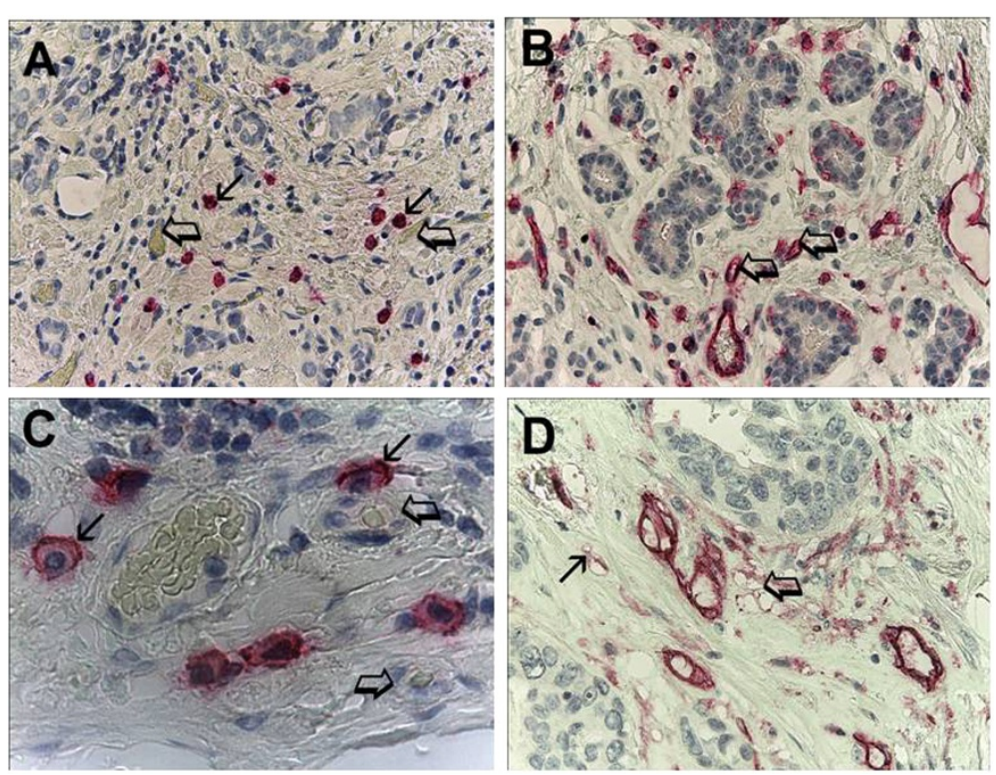

Figure 1 Immunostaining of breast cancer sections with anti-tryptase and anti-CD34 antibodies. (A) Small arrows indicate a single red mast cell positive to tryptase. Big arrows indicate a single blood vessel with many red blood cells in their lumen. High MCDPT at x400 magnification $\left(0.19 \mathrm{~mm}^{2}\right.$ area). (B) Arrows indicate a single red positive microvessel immunostained with a primary anti CD-34 antibody. High MVD at $\times 400$ magnification $\left(0.19 \mathrm{~mm}^{2}\right.$ area). (C) Details of breast cancer section immunostained with a primary anti-tryptase antibody. Small arrows indicate a single red mast cell positive to tryptase, note the blue nucleus of mast cell. Big arrows indicate a single microvessel with a red blood cell in their lumen. X1000 magnification in oil. (D) Details of breast cancer section immunostained with a primary anti-CD-34 antibody. Small arrow indicates two red positive microvessels. Big arrow indicates a cluster of microvessels. X1000 magnification in oil. 
Table 2 MCDPT, MVD, STLBS and STLAS means \pm 1 standard deviations in a series of 105 breast cancer patients

\begin{tabular}{cccc}
\hline MCDPT & $M V D$ & & \\
$400 x$ & $400 x$ & $S T L B S$ & $S T L A S$ \\
magnification & $\begin{array}{c}\text { magnification } \\
\left(0.19 \mathrm{~mm}^{2} \text { area }\right)\end{array}$ & $\mu \mathrm{g} / \mathrm{L}$ & $\mu \mathrm{g} / \mathrm{L}$ \\
$\left(0.19 \mathrm{~mm}^{2}\right.$ area $)$ & & \\
\hline$* 8.35 \pm 2.99$ & $* 30.11 \pm 8.24$ & $* 7.18 \pm 2.63$ & $5.13 \pm 2.21$ \\
\hline
\end{tabular}

*Mean \pm 1 standard deviation.

t-test: $\mathrm{p}=0.0001$.

Pearson correlation between MVD and STLBS: $r=0.81 ; p=0.0001$

Pearson correlation between MVD and MCDPT: $r=0.77 ; p=0.0001$.

Pearson correlation between STLBS and MCDPT: $r=0.69 ; p=0.0003$.

\section{Immunohistochemistry}

The histological diagnosis was made on haematoxylineosin-stained slides and histopathological grading was performed according to the criteria described by Bloom and Richardson, as well, moderately and poorly differentiated state [32]. For the evaluation of MCDPT and MVD a three-layer biotin-avidin-peroxidase system was utilized [33]. Briefly, six- $\mu$ m-thick serial sections of formalin-fixed and paraffin-embedded biopsy tumour were cut. Then, sections were microwaved at $500 \mathrm{~W}$ for 10 min, after which endogenous peroxidase activity was blocked with 3\% hydrogen peroxide solution. Adjacent sections were stained with human-specific monoclonal antibodies anti-tryptase (clone AA1; Dako, Glostrup, Denmark) diluted 1:100 for $1 \mathrm{~h}$ at room temperature and anti-CD34 (QB-END 10; Bio-Optica Milan, Italy) diluted 1:50 for $1 \mathrm{~h}$ at room temperature, respectively. The bound antibody was visualized using a biotinylated secondary antibody, avidin-biotin peroxidase complex and fast red. Nuclear counterstaining was performed with Gill's haematoxylin no. 2 (Polysciences, Warrington, PA, USA). The primary antibody was omitted in negative controls.

\section{Morphometrical assay}

An image analysis system (Quantimet500 Leica, Wetzlar, Germany) was utilized [33]. The five areas with higher immunostaining ('hot spots') were selected at low magnification and individual MCDPT (Figure 1A) and MVD (Figure 1B) were counted at $\times 400$ magnification $\left(0.19 \mathrm{~mm}^{2}\right.$ area). The details of MCDPT and MVD were evaluated at x1000 magnification in oil (Figure 1C and $\mathrm{D}$, respectively).

\section{Statistical analysis}

MCDPT and MVD mean values \pm 1 standard deviations (s.d.) were evaluated by two independent observers (V.Z. and G.R.) for each tumor sample and in all series of sections. Correlations between STLBS, MCDPT, and MVD were calculated using Pearson's ( $r$ ) analysis. The correlations between the above indexes and the clinicopathological features listed in Table 1 were analyzed by the Chi-square test. All statistical analyses were performed with the SPSS statistical software package (SPSS, Inc., Chicago, IL).

\section{Results}

The mean \pm 1 s.d. STLBS and STLAS were $7.18 \pm$ $2.63 \mu \mathrm{g} / \mathrm{L}$ and $5.13 \pm 2.21 \mu \mathrm{g} / \mathrm{L}$ respectively, and a significant difference between mean levels was found $(\mathrm{p}=$ 0.0001 ) by t-test (Table 2, Figure 2). The mean \pm 1 s.d. of MCDPT and MVD was $8.35 \pm 2.99$ and $30.11 \pm 8.24$ respectively (Table 2). A significant correlation between STLBS and MVD $(r=0.81, p=0.0001)$, MCDPT and $\operatorname{MVD}(r=0.73 ; p=0.001)$, STLBS and MCDPT $(r=0.60$, $\mathrm{p}=0.003$ ) was found (Figure 3 ).

\section{Discussion}

It has been well established that MCs are involved in tumor development [6-9] angiogenesis-mediated both in animal and human malignancies [9-22]. However, few

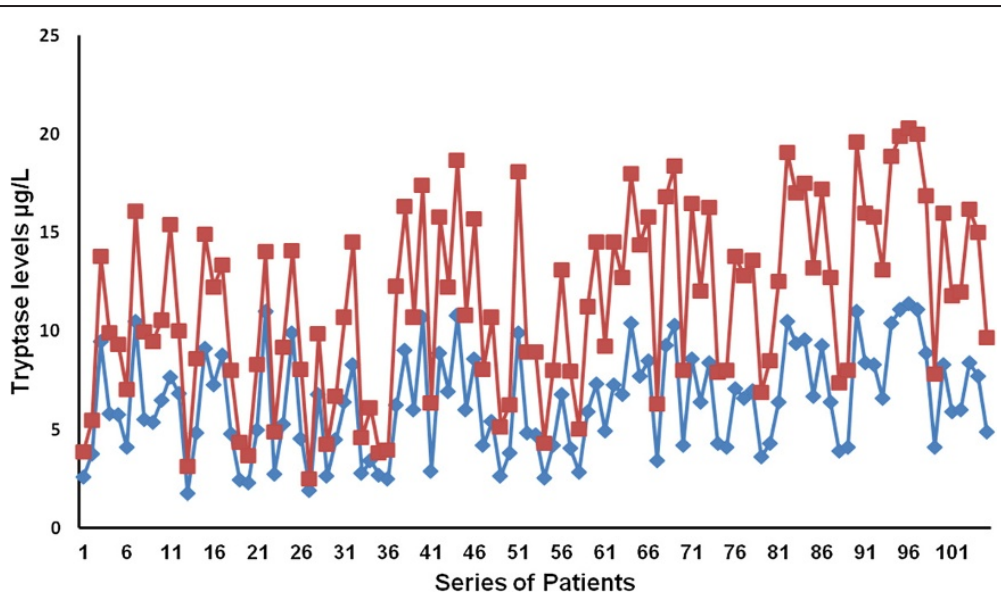

Figure 2 Tryptase levels before (STLBS) and after (STLAS) surgery in a series of 105 breast cancer patients. 


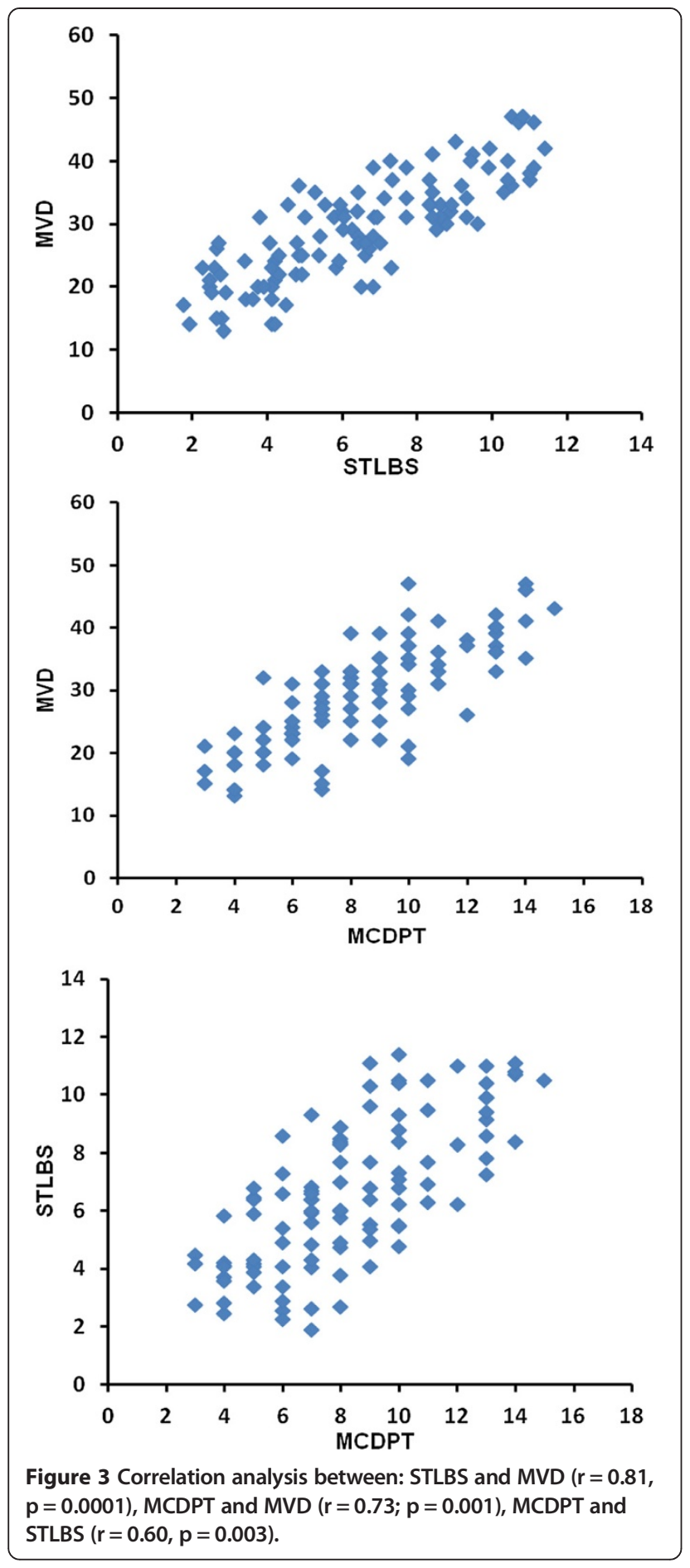

data have been published about the role of tissue MCDPT in $\mathrm{BC}$ angiogenesis and development $[7,8,30]$. Interestingly, no reports have been published regarding the role of serum tryptase in $\mathrm{BC}$ angiogenesis and as a circulating surrogate predictive marker.

In this pilot study we have shown for the first time that STLBS strongly correlates with MCDPT and MVD in primary tumor tissue. Our data also demonstrates that STLAS significantly decrease in BC patients. Due to the release of tryptase from MCs, we suggest that MCDPT in primary $\mathrm{BC}$ tumor tissue represents the main source of serum tryptase. In our hypothesis, if primary tumor tissue is completely removed STLAS should decrease in one day due to their approximately 4-h long life-cycle. For these reasons, we detected STLAS $24 \mathrm{~h}$ before surgery to evaluate their possible role as a circulating surrogate marker suggesting the presence of tumor tissue, and again $24 \mathrm{~h}$ after treatment to confirm its decrease and, as a consequence, its possible expression of the absence of tumor tissue. We elaborate the background of our hypothesis based on previously published pilot data, which suggested an increase of MCDPT in primary tumor tissue. In these studies MCDPT was correlated with MVD, suggesting its role in $B C$ angiogenesis $[7,30]$. Our data suggested an involvement of MCs and tryptase in $\mathrm{BC}$ angiogenesis. Interestingly, published studies already demonstrated an involvement of tissue MCDPT in other malignancies such as squamous carcinoma, gastrointestinal cancer, non-small cell lung cancer, melanoma, and endometrial carcinoma $[9,11,12,18,19]$. However, the above studies did not focus on the changes inSTLs before and after surgery, and no correlation between STLs, MCDPT and MVD was evaluated. It is remarkable that tryptase released from MCs is involved in tumor angiogenesis by several mechanisms. Firstly, tryptase stimulates the formation of vascular tubes in in vitro and in vivo experimental models; secondly, tryptase is an agonist of the PAR-2 in vascular endothelial cells that, in turn, induces angiogenesis [34]; thirdly, tryptase may stimulate the release of latent angiogenic factors bound to the extracellular matrix $[21,35]$. Overall, the above data suggest that tryptase may be a potential surrogate bio-marker of tumor angiogenesis which is able to predict response to surgical treatment.

\section{Conclusions}

If the primary source of tryptase production is no longer existing, after $24 \mathrm{~h}$ a significant reduction in STLs should be expected. If elevated STLs persist after surgery, this would suggest that residual tumor tissue remains after surgical resection or, alternatively, that unknown metastases are present. In this context, several tryptase inhibitors, such as gabexate or nafamostat mesilate, may be evaluated in future clinical trials as a new anti-tumor and antiangiogenic approach.

\section{Abbreviations}

STLBS: Serum tryptase levels before surgery; STLAS: Serum tryptase levels after surgery; MCDPT: Mast cell density positive to tryptase;

MVD: Microvascular density; BC: Breast cancer; MCs: Mast cells; VEGF: Vascular endothelial growth factor; FGF-2: Fibroblast growth factor-2; MCD: Mast cells density; PAR-2: Proteinase-activated receptor-2; UICC-TNM: International union against cancer tumor node metastasis; s.d.: Standard deviations. 


\section{Competing interests}

The authors declare that they have no competing interests.

\section{Authors' contributions}

IM and GR designed the study, conducted experiments, analysed and interpreted data and wrote the manuscript. MA, CDG and DR ensured protocol integrity and collected data. MA, GSC, RS, RP, RR, ES and DR conducted experiments and collected data. RP, ML, VZ analysed and interpreted data. All authors reviewed the manuscript. All authors read and approved the final manuscript.

\section{Acknowledgements}

This study was in part supported by a grant from the "Alleanza Contro il Cancro" project, the Italian National Health Institute and the Italian Ministry of Health and "Associazione Italiana Mastocitosi".

\section{Author details}

${ }^{1}$ Interventional Radiology Unit with Integrated Section of Translational Medical Oncology, National Cancer Research Centre IstitutoTumori "Giovanni Paolo II", Bari, Italy. 'Department of Medical and Surgery Science, Clinical Surgery Unit, University of Catanzaro "Magna Graecia" Medical School, Catanzaro, Italy. ${ }^{3}$ Section of Animal Health, Department of Prevention, ASL BAT, Bari, Italy. ${ }^{4}$ Department of Medical and Surgery Science, Cardiovascular Disease Unit, University of Catanzaro "Magna Graecia" Medical School, Catanzaro, Italy. ${ }^{5}$ Department of Medical and Surgery Science, Pathology Unit, University of Catanzaro "Magna Graecia" Medical School, Catanzaro, Italy. ${ }^{6}$ Department of Experimental Oncology, Clinical Pathology Laboratory National Cancer Research Centre IstitutoTumori "Giovanni Paolo II", Bari, Italy. ${ }^{7}$ Department of Basic Medical Sciences, Neurosciences and Sensory Organs, University of Bari Medical School, Bari, Italy. ${ }^{8}$ National Cancer Institute "Giovanni Paolo II", Bari, Italy.

Received: 29 January 2014 Accepted: 14 July 2014

Published: 24 July 2014

\section{References}

1. Galli SJ, Kalesnikoff J, Grimbaldeston MA, Piliponsky AM, Williams CM, Tsai M: Mast cells as "tunable" effector and immunoregulatory cells: recent advances. Annu Rev Immunol 2005, 23:749-786.

2. Ribatti $D$, Crivellato E: Mast cells, angiogenesis and cancer. Adv Exp Med Biol 2011, 716:270-288

3. Ribatti D, Guidolin D, Marzullo A, Nico B, Annese T, Benagiano V, Crivellato E: Mast cells and angiogenesis in gastric carcinoma. Int J Exp Pathol 2010, 91:350-356.

4. Ranieri G: Hot topic: targeting tumor angiogenesis: an update. Curr Med Chem 2012, 19:937.

5. Theoharides TC, Conti P: Mast cells: the Jekyll and Hyde of tumor growth. Trends Immunol 2004, 25:235-241.

6. Ranieri G, Coviello M, Chiriatti A, Stea B, Montemurro S, Quaranta M, Dittad $\mathrm{R}$, Paradiso A: Vascular endothelial growth factor assessment in different blood fractions of gastrointestinal cancer patients and healthy controls. Oncol Rep 2004, 11:435-439.

7. Mangia A, Malfettone A, Rossi R, Paradiso A, Ranieri G, Simone G, Resta L: Tissue remodelling in breast cancer: human mast cell tryptase as an initiator of myofibroblast differentiation. Histopathology 2011, 58:1096-1106.

8. Ranieri G, Ammendola M, Patruno R, Celano G, Zito FA, Montemurro S, Rella A, Di Lecce V, Gadaleta CD, Battista De Sarro G, Ribatti D: Tryptase-positive mast cells correlate with angiogenesis in early breast cancer patients. Int J Oncol 2009, 35:115-120.

9. Ranieri G, Labriola A, Achille G, Florio G, Zito AF, Grammatica L, Paradiso A: Microvessel density, mast cell density and thymidine phosphorylase expression in oral squamous carcinoma. Int J Oncol 2002, 21:1317-1323.

10. Tomita M, Matsuzaki Y, Edagawa M, Shimizu T, Hara M, Sekiya R, Onitsuka T: Association of mast cells with tumor angiogenesis in esophageal squamous cell carcinoma. Dis Esophagus 2001, 14:135-138.

11. Ribatti D, Finato N, Crivellato E, Marzullo A, Mangieri D, Nico B, Vacca A, Beltrami CA: Neovascularization and mast cells with tryptase activity increase simultaneously with pathologic progression in human endometrial cancer. Am J Obstet Gynecol 2005, 193:1961-1965.

12. Ammendola M, Sacco R, Donato G, Zuccalà V, Russo E, Luposella M, Vescio G, Rizzuto A, Patruno R, De Sarro G, Montemurro S, Sammarco G, Ranieri G: Mast cell positivity to tryptase correlates with metastatic lymph nodes in gastrointestinal cancer patients treated surgically. Oncology 2013, 85:111-116. doi:10.1159/000351145.

13. Acikalin MF, Oner U, Topçu I, Yaşar B, Kiper H, Colak E: Tumour angiogenesis and mast cell density in the prognostic assessment of colorectal carcinomas. Dig Liver Dis 2005, 37:162-169.

14. Gulubova M, Vlaykova T: Prognostic significance of mast cell number and microvascular density for the survival of patients with primary colorectal cancer. J Gastroenterol Hepatol 2009, 24:1265-1275.

15. Esposito I, Menicagli M, Funel N, Bergmann F, Boggi U, Mosca F, Bevilacqua G, Campani D: Inflammatory cells contribute to the generation of an angiogenic phenotype in pancreatic ductal adenocarcinoma. J ClinPathol 2004, 57:630-636.

16. Tuna B, Yorukoglu K, Unlu M, Mungan MU, Kirkali Z: Association of mast cells with microvessel density in renal cell carcinomas. Eur Urol 2006, 50:530-534.

17. Carlini MJ, Dalurzo MC, Lastiri JM, Smith DE, Vasallo BC, Puricelli LI, de Cidre Lauría LS: Mast cell phenotypes and microvessels in non-small cell lung cancer and its prognostic significance. Hum Pathol 2010, 41:697-705.

18. Ribatti D, Ennas MG, Vacca A, Ferreli F, Nico B, Orru S, Sirigu P: Tumor vascularity and tryptase-positive mast cells correlate with a poor prognosis in melanoma. Eur J Clin Invest 2003, 33:420-425.

19. Benítez-Bribiesca L, Wong A, Utrera D, Castellanos E: The role of mast cell tryptase in neoangiogenesis of premalignant and malignant lesions of the uterine cervix. J Histochem Cytochem 2001, 49:1061-1062.

20. Ranieri G, Patruno R, Lionetti A, Di Summa A, Mattioli E, Bufo P, Pellecchia A, Ribatti D, Zizzo N: Endothelial area and microvascular density in a canine non-Hodgkin's lymphoma: an interspecies model of tumor angiogenesis. Leuk Lymphoma 2005, 46:1639-1643.

21. Nico B, Mangieri D, Crivellato E, Vacca A, Ribatti D: Mast cells contribute to vasculogenic mimicry in multiple myeloma. Stem Cells Dev 2008, 17:19-22.

22. Ribatti D, Molica S, Vacca A, Nico B, Crivellato E, Roccaro AM, Dammacco F: Tryptase-positive mast cells correlate positively with bone marrow angiogenesis in B-cell chronic lymphocytic leukemia. Leukemia 2003, 17:1428-1430

23. Blair RJ, Meng H, Marchese MJ, Ren S, Schwartz LB, Tonnesen MG, Gruber BL: Human mast cells stimulate vascular tube formation. Tryptase is a novel, potent angiogenic factor. J Clin Invest 1997, 99:2691-2700.

24. Stack MS, Johnson DA: Human mast cell tryptase activates single-chain urinary-type plasminogen activator (pro-urokinase). J Biol Chem 1994, 269:9416-9419.

25. Ribatti D, Ranieri G, Nico B, Benagiano V, Crivellato E: Tryptase and chymase are angiogenic in vivo in the chorioallantoic membrane assay. Int J DevBiol 2011, 55:99-102.

26. Itoh Y, Sendo T, Oishi R: Physiology and pathophysiologyof proteinase-activated receptors (P ARs): role of tryptase/P AR-2 in vascular endothelial barrier function. J Pharmacol Sci 2005, 97:14-19.

27. Shpacovitch VM, Brzoska T, Buddenkotte J, Stroh C, Sommerhoff CP, Ansel JC, Schulze-Osthoff K, Bunnett NW, Luger TA, Steinhoff M: Agonists of proteinase-activated receptor- 2 induce cytokine release and activation of nuclear transcription factor kappa $B$ in human dermal microvascular endothelial cells. J Invest Dermatol 2002, 118:380-385.

28. Matej $R$, Mandàkovà $P$, Netikovà $I$, Pouckovà $P$, Olejàr T: Proteinaseactivated receptor-2 expression in breast cancer and the role of trypsin on growth and metabolism of breast cancer cell line MDA MB-231. Physiol Res 2007, 56:475-484.

29. Morris DR, Ding Y, Ricks TK, Gullapalli A, Wolfe BL, Trejo J: Proteaseactivated receptor-2 is essential for factor VIla and Xa-induced signaling, migration, and invasion of breast cancer cells. Cancer Res 2006, 66:307-314.

30. Ribatti $D$, Finato N, Crivellato $E$, Guidolin D, Longo V, Mangieri D, Nico B, Vacca A, Beltrami CA: Angiogenesis and mast cells in human breast cancer sentinel lymphnodes with and without micrometastases. Histopathology 2007, 51:837-842.

31. Singletary SE, Connolly JL: Breast cancer staging: working with the sixth edition of the AJCC Cancer Staging Manual. CA Cancer J Clin 2006, 56:37-47.

32. Bloom HJ, Richardson WW: Histological grading and prognosis in breast cancer; a study of 1409 cases of which 359 have been followed for 15 years. Br J Cancer 1957, 11:359-377.

33. Ranieri G, Grammatica L, Patruno R, Zito AF, Valerio P, lacobellis S, Gadaleta C, Gasparini G, Ribatti D: A possible role of thymidine phosphorylase 
expression and 5-fluorouracil increased sensitivity in oropharyngeal cancer patients. J Cell Mol Med 2007, 11:362-368.

34. Liu Y, Mueller BM: Protease-activated receptor-2 regulates vascular endothelial growth factor expression in MDAMB 231 cells via MAPK pathways. Biochem Biophys Res Commun 2006, 344:1263-1270.

35. Hallegren J, Estrada S, Karlson U, Karlson U, Alving K, Pejler G: Heparin antagonists are potent inhibitors of mast cell tryptase. Biochemistry 2001, 40:7342-7439

doi:10.1186/1471-2407-14-534

Cite this article as: Marech et al: Serum tryptase, mast cells positive to tryptase and microvascular density evaluation in early breast cancer patients: possible translational significance. BMC Cancer 2014 14:534.

\section{Submit your next manuscript to BioMed Central and take full advantage of:}

- Convenient online submission

- Thorough peer review

- No space constraints or color figure charges

- Immediate publication on acceptance

- Inclusion in PubMed, CAS, Scopus and Google Scholar

- Research which is freely available for redistribution 